\title{
Anti-inflammatory activity of methanolic extract of Ficus hispida dried fruit
}

\author{
Asif Choudhury*, Deepak Kumar Jha, U. Rajashekhar
}

Department of Pharmacology, Karnataka College of Pharmacy, Bangalore, Karnataka, India

Received: 31 May 2021

Accepted: 24 June 2021

*Correspondence:

Asif Choudhury,

Email: asif.choudhury09@gmail.com

Copyright: $@$ the author(s), publisher and licensee Medip Academy. This is an open-access article distributed under the terms of the Creative Commons Attribution Non-Commercial License, which permits unrestricted non-commercial use, distribution, and reproduction in any medium, provided the original work is properly cited.

\section{ABSTRACT}

Background: Natural products are a valuable resource of novel bioactive metabolites and these products exist in which the anti-inflammatory activity. The present investigation studies the in vivo and in vitro anti-inflammatory activity of methanolic extract of Ficus hispida in rat's model.

Methods: Plant material was extracted with methanol in a Soxhlet extraction apparatus. Indomethacin was used as a standard drug here, which is a known potent inhibitor of PG synthesis. The carrageenin and histamine induced paw oedema were selected to represent models of acute inflammations. The test compounds and standard drugs were administered orally. After 60 minutes paw oedema was induced by giving $0.1 \mathrm{ml}$ of $1 \%$ Carrageenan and $0.1 \%$ histamine by sub-plantar administration. Paw volume-Plethysmometer by mercury displacement method, before and after $1 \mathrm{hr}$ to 4 hours of carrageenan and histamine administration. Performed MTT-based cytotoxicity assay of the Ficus hispida on the RAW264.7 cell line to determine the $\mathrm{IC}_{50}$ and calculate the pro-inflammatory cytokines viz, IL-6, IL-1 $\beta$ and TNF- $\alpha$ and compared to the LPS control.

Results: The result obtained from the in-vivo study shows that the Ficus hispida has significant anti- inflammatory activity in a dose dependent manner. This effect is similar to that produced by NSAIDS such as Indomethacin. The concentrations of IL- 6 , IL- $1 \beta$ and TNF- $\alpha$, secreted by the cells after challenging with bacterial LPS $(2 \mu \mathrm{g} / \mathrm{ml})$ and subsequent treatment with $50 \mu \mathrm{g}$ Ficus hispida has been found to reduce the production of all the three pro-inflammatory cytokines viz, IL-6, IL-1 $\beta$ and TNF- $\alpha$ as compared to the LPS control. The activity, in fact, is comparable to the standard NSAID Indomethacin.

Conclusions: All these findings and phytoconstituents present in the extract could be the possible chemicals involved in the prevention of inflammations.

Keywords: Ficus hispida, Anti-inflammatory activity, Pro-inflammatory methanol, Histamine, Carrageenan

\section{INTRODUCTION}

Inflammation is a non-specific, localized immune reaction of the organism, which tries to localize the pathogenic agents. Many consider the syndrome a self-defense mechanism. It consists in vascular, metabolic, cellular changes, triggered by the entering of pathogenic agents in healthy tissues of the body. ${ }^{1}$ Oedema formation, leukocyte infiltration and granuloma formation represents such components of inflammation. ${ }^{2}$ Oedema formation in the paw is the result of a synergism between various inflammatory mediators that increase vascular permeability/or the mediators that increase blood flow. ${ }^{3}$ NSAIDs, steroidal drugs and immune-suppressant drugs which have been usually used in the relief of inflammatory diseases worldwide for a long time are often associated with severe adverse side effects, such as gastrointestinal bleeding and peptic ulcer Valiollah et al. For this reason, in recent time, more interest is shown in alternative and natural drugs for treatment of various diseases; but there is a lack of scientific evidence Shukla et al. The use of plant preparations and extracts of their anti-inflammatory properties has a long-standing history among Indian 
physicians. In this regard, one such plant which has number of traditional uses is Ficus hispida.

Ficus hispida is a part of the Moraceae family. It is often a famous and extensively disbursed throughout subcontinent and India. ${ }^{4}$ The crops were consists of phenanthroindolizidine alkaloids, triterpenoids, flavonoids, oxyterpene, n-alkanes, coumarins, tannins, and saponins, oleanolic acid, bergapten, $\beta$-sitosterol, $\beta$-amyrin, hispidin. The bark contains 10-ketotetracosyl arachidate, lupeol acetate, $\beta$-amyrin and triacontanol acetate. The fruit contains linalool, linalool oxide, terpeneol, and 2,6dimethyl-1,7-octadiene-3,6-diol. The plant additionally includes ficushispimines $\mathrm{A}$ and $\mathrm{B}$, ficushispidine, hispiloscine, $\mathrm{N}$-triacontanyl acetate, ficusin A. ${ }^{5-7}$ Newly isolated 2 enormous phenanthroindolizidine alkaloids, 6O-methyltylophorinidine and 2-demethoxytylophorine, and a novel biphenyl-hexahydroindolizine hispidine.

Ficus hispida Linn is an important pharmacological activity, The extracts hold been stated to be bitter, astringent, and anti-dysenteric and recreation against piles, jaundice, psoriasis, anemia, then hemorrhage. ${ }^{8,9}$ The fruit acts as like a coolant and tonic, the juice is instituted as a moderate purgative. Its leaves are an anti-diarrheal, antiinflammatory, anti-tussive, anti-pyretic, astringent, haemostatic and anti-ulcer activity, anti-diabetic, antibacterial, hepatoprotective properties. $^{10-13}$ Beside antioxidant activity, phenolic compounds are antiallergic, antimicrobial activity, cardio-protective, anti-thrombotic and vasodilator effect. ${ }^{14,15}$ A mixture of honey and its juice is a good antihemorrhagic. ${ }^{16}$

\section{METHODS}

\section{Collection of plant material}

The Ficus hispida (FH) fruits were brought from Guwahati, Assam India. The plant specimen has been identified and authenticated by Dr. P. P. Baruah, department of botany, Guwahati university and reg. no. Herb./Bot./GU./2020/49.

\section{Extraction of Ficus hispida fruits by using Soxhlet's extractor and sample preparation}

The dried fruits were powdered and passed through the sieve and used for the preparation of methanolic extract. $250 \mathrm{gm}$ of dried powder of Ficus hispida fruits was subjected to successive extraction in a Soxhlet extractor with methanol, and dried extract used for further experimental test. ${ }^{17-21}$

\section{Experimental animals}

Wistar rat's male (8-10 weeks old) weighing 150-200 gm and Albino mice female (8-10 weeks old) weighing 20-25 gm were used for the experiment. All the experiments conducted on the animals were in accordance with the standards set for the use of the laboratory animal use and the experimental protocols were duly approved by the IAEC of Karnataka college of pharmacy, Bangalore (Reg. number: 1564/PO/Re/S/11/CPCSEA).

\section{Acute oral toxicity studies for dose fixation}

The acute oral toxicity study was performed according to the OECD guidelines no. 425 . A dose of $1 / 10^{\text {th }}$ and $1 / 20^{\text {th }}$ was considered to be high dose and low dose prepared by dissolving in miliQ water. The doses were prepared as per the OECD guideline no. 425.

\section{Detailed study plan}

The following procedure was done, where $n=6$ animals in each group.

Table 1: Carrageenan induced rat paw edema model. ${ }^{22,23}$

\begin{tabular}{|c|c|c|}
\hline Groups & & No. of rats \\
\hline \multirow{4}{*}{$\begin{array}{l}\text { Carrageenan } \\
\text { induced rat } \\
\text { hind paw } \\
\text { edema } \\
\text { model }\end{array}$} & $\begin{array}{l}\text { Group I: Control group- } \\
0.1 \mathrm{ml} \text { of } 1 \% \\
\text { carrageenan by sub- } \\
\text { plantar administration. }\end{array}$ & 6 \\
\hline & $\begin{array}{l}\text { Group II: Standard } \\
\text { group (Indomethacin } 10 \\
\text { mg/kg/P.O.) }\end{array}$ & 6 \\
\hline & $\begin{array}{l}\text { Group III: Test group- } \\
\text { FH Low dose }\end{array}$ & 6 \\
\hline & $\begin{array}{l}\text { Group IV: Test group- } \\
\text { FH High dose }\end{array}$ & 6 \\
\hline
\end{tabular}

Table 2: Histamine induced rat paw oedema model.

\begin{tabular}{|lll|}
\hline Groups & \multicolumn{1}{c}{ No. of rats } \\
\hline & $\begin{array}{l}\text { Group I: Control group- } \\
\text { histamine, } 100 \mu 1,0.1 \%\end{array}$ & 6 \\
\cline { 2 - 3 } $\begin{array}{l}\text { Histamine } \\
\text { induced rat } \\
\text { hind paw } \\
\text { edema } \\
\text { model }\end{array}$ & $\begin{array}{l}\text { Group II: Standard group } \\
\text { (Indomethacin } 10\end{array}$ & 6 \\
& $\begin{array}{l}\text { Group III: Test group- } \\
\text { FH low dose }\end{array}$ & 6 \\
& $\begin{array}{l}\text { Group IV: Test group- } \\
\text { FH high dose }\end{array}$ & 6 \\
\hline
\end{tabular}

Histamine-induced inflammation has been widely used to explore the anti-inflammatory effects of some medicinal plants. $^{24}$

The following procedure was done, where $n=6$ animals in each group.

The test compounds and standard drugs were administered orally.

After 60 min paw oedema was induced by giving $0.1 \mathrm{ml}$ of $1 \%$ carrageenan and $100 \mu 1,0.1 \%$ histamine by sub-plantar administration. Paw volume-Plethysmometer by mercury 
displacement method, before and after 1, 2, 3 and $4 \mathrm{~h}$ of administration.

\section{Evaluation}

The anti-inflammatory effect of fruits of methanolic extract $\mathrm{FH}$ was calculated by the following equation: Antiinflammatory activity $(\%)=$ Do-Dt/Do $\times 100$, where DO was the average inflammation (hind paw oedema) of the control group of rats at a given time; and Dt was the average inflammation of the drug treated (i.e. extracts or reference indomethacin) rats at the same time.

To study the in vitro anti-inflammatory activity by estimating followings; cell line-mouse macrophages RAW264.7. RAW264.7 cell line was procured from national centre of cell science, Pune.

\section{Performing MTT assay-to find out the in vitro dose IC 50 on the cell line ${ }^{25}$}

RAW264.7 cell line was procured from national centre of cell science, Pune, cultured in DMEM medium, $10 \%$ fetal bovine serum and antibiotics incubated at $37^{\circ} \mathrm{C}$ in $5 \% \mathrm{CO}_{2}$.

A range of concentration of $\mathrm{FH}$ used per well as follows; $0.7,1.5,3.1,6.25,12.5,25,50,100,200,400,600,800$, $1000 \mu \mathrm{g} / \mathrm{ml}$ and incubated at $37^{\circ} \mathrm{C}$ for $24 \mathrm{~h}$ and then processed for determining cell viability.

At the end of drug exposure period, the growth medium was aspirated from each well and $50 \mu \mathrm{L}$ of MTT solution $(5 \mathrm{mg} / \mathrm{ml})$ was added to each well. The plate was incubated for 4 hours at $37^{\circ} \mathrm{C}$ in dark to facilitate the formation of formazan crystals. After incubation $200 \mu \mathrm{L}$ of acidified DMSO was added to each well to dissolve the formazan crystals to give a purple color. Add $25 \mu \mathrm{L}$ of glycine buffer and measure absorbance at $570 \mathrm{~nm}$ in a plate reader. The $\mathrm{IC}_{50}$ of the test samples were calculated. The percentage of death of the cells was determined by 100-(Abs. of sample/abs. of control $\times 100)$.

\section{In vitro anti-inflammatory assay on $R A W 264.7$ cells and measuring the levels of inflammatory cytokines of $I L$ - 1beta, IL-6 and TNF-alpha by ELISA assay ${ }^{26-30}$}

RAW264.7 cells were cultured in a 12-well plate at a seeding density of $5 \times 10^{5}$ cells per well and cultured at $37^{\circ} \mathrm{C}$ in a humidified atmosphere of $5 \% \mathrm{CO}_{2}$ in air in DMEM medium.

After incubation, the culture media were aspirated from each well without disturbing the cell monolayer and centrifuged at $10,000 \mathrm{rpm}$ at $4^{\circ} \mathrm{C}$ for 5 mins to sediment particulate matter, if any. The supernatants were used for the estimation of the cytokines viz, IL-1 $\beta$, IL- 6 and TNF$\alpha$ was done using antigen capture ELISA.

The ELISA well plates have been coated with $100 \mu \mathrm{l}$ of IL-6, IL- $1 \beta$ and TNF- $\alpha$ primary antibodies $(2.5 \mu \mathrm{g} / \mathrm{ml})$ in carbonate buffer $\left(\mathrm{Na}_{2} \mathrm{HPO}_{4}\right.$ and $\mathrm{NaH}_{2} \mathrm{PO}_{4}, \mathrm{pH}$ 9.6). Primary antibodies of IL-6, IL- $1 \beta$, and TNF- $\alpha$ were used. Plates have been incubated overnight at $4^{\circ} \mathrm{C}$ to facilitate proper adsorption of antibodies on to substrate. After 12$14 \mathrm{~h}$ of incubation, plates have been washed thrice with washing buffer i.e., $\mathrm{NaCl}$ and tween 20 in phosphate buffer, pH-7.4 and blocked with $250 \mu \mathrm{l}$ of blocking buffer i.e., BSA in phosphate buffer, $\mathrm{pH} 7.4$ / well.

After followed by incubation at $37^{\circ} \mathrm{C}$ for $1 \mathrm{~h}$, added standard cytokines for construction of calibration curve. Remaining wells had been coated with $100 \mu$ l of diluted cell lysate. Concentration range used for standards was-25, $12.5,6.25,3.125,1.562,0.781,0.39$ and $0.195 \mathrm{ng} / \mathrm{ml}$.

The standard cytokines were used, incubated for $1 \mathrm{~h}$ and washed thrice. Anti-cytokine antibodies such as; anti IL-6, IL-1 $\beta$ and then anti TNF- $\alpha$ monoclonal antibodies were diluted 1:1000 and added $100 \mu \mathrm{l}$ per well to the strips containing the respective antigens and incubated at $37^{\circ} \mathrm{C}$ for 1 hour. After incubation, $100 \mu \mathrm{l}$ of HRP-conjugate was added. Plate incubated at $37^{\circ} \mathrm{C}$ for 1 hour. Then $100 \mu \mathrm{l}$ of freshly prepared substrate i.e., TMB in DMSO containing $\mathrm{H}_{2} \mathrm{O}_{2}$ was added to all wells. After incubation in dark $37^{\circ} \mathrm{C}$ for $15 \mathrm{mins}$, color has changed, the reaction has been terminated by adding $50 \mu \mathrm{l}$ of $2.5 \mathrm{~N} \mathrm{H}_{2} \mathrm{SO}_{4}$ per well and the A $450 \mathrm{~nm}$ was measured by using ELISA reader.

A standard calibration graph was plotted (abs vs conc.) and the concentrations of unknown samples have been determined from the graph.

Table 3: Each group was added of RAW264.7 cells in triplicate $(n=3)$ manner and has been treated with test chemical.

\begin{tabular}{|ll|}
\hline S. no. & Groups \\
\hline Group 1 & $\begin{array}{l}\text { Normal control-cells in growth medium, } \\
\text { DMEM }\end{array}$ \\
\hline Group 2 & Lipopolysaccharide (LPS) control-2 $\mu \mathrm{g} / \mathrm{ml}$ \\
\hline Group 3 & $\begin{array}{l}\text { Treated group-LPS+ Ficus hispida, 50 } \\
\mu \mathrm{g} / \mathrm{ml}\end{array}$ \\
\hline Group 4 & Standard: LPS + indomethacin, $2.5 \mu \mathrm{g} / \mathrm{ml}$ \\
\hline
\end{tabular}

\section{Statistical analysis}

The results are expressed as mean \pm S.E.M. from $n=6$ rats in each group. Data were analysed using statistical software Graph Pad prism version 5. The significance of difference among the groups was assessed using one-way analysis of variance (ANOVA) followed by Tukey's test compared between normal control (untreated) vs all groups $\mathrm{p}<0.05$ were considered significant.

\section{RESULTS}

\section{Yield of extraction}

Yield of methanolic extract of Ficus hispida fruits was $46.08 \%$. 


\section{Acute toxicity study}

The $2000 \mathrm{mg} / \mathrm{kg}$ body weight was tolerated dose and no signs of toxicity have been found. Hence, $1 / 10^{\text {th }}$ and $1 / 20^{\text {th }}$ of the same dose was selected; $100 \mathrm{mg} / \mathrm{kg}$ and $200 \mathrm{mg} / \mathrm{kg}$ respectively and the further study were carried out.

\section{Evaluation of in-vivo anti-inflammatory activity}

Control group received an equivalent volume of vehicle only, standard group received indomethacin at the dose of $10 \mathrm{mg} / \mathrm{kg}$ and test drug Ficus hispida extract received low dose $100 \mathrm{mg} / \mathrm{kg}$ and high $200 \mathrm{mg} / \mathrm{kg}$ P.O. respectively.

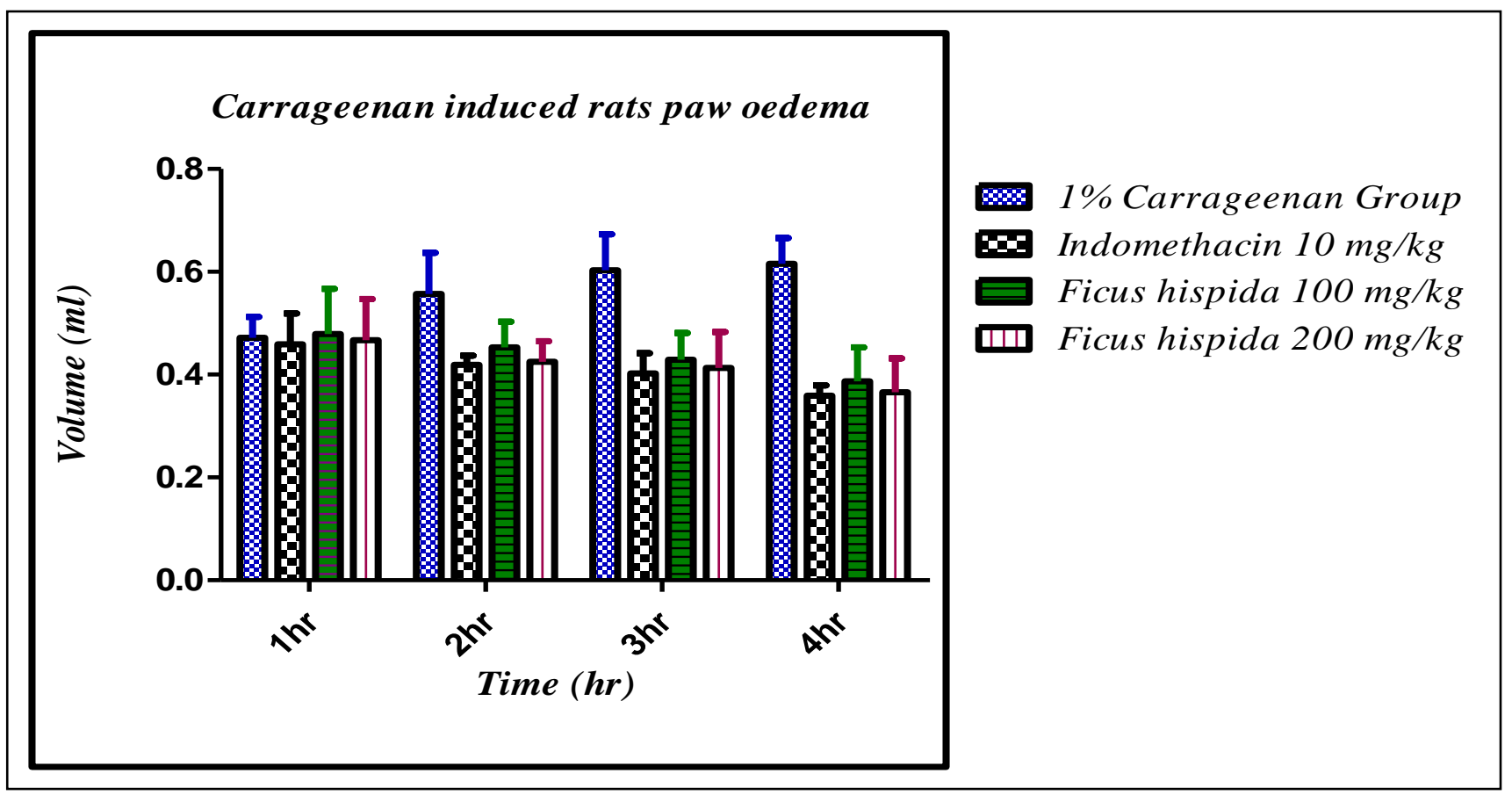

Values are expressed as mean $\pm S E M ; n=6^{* * *} p<0.001,{ }^{* *} p<0.01,{ }^{*} p<0.05$ when compared with carrageenan $(p<0.05)$, \#\#\# $<<0.001$, ${ }^{\#} p<0.01,{ }^{\#} p<0.05$ when compared with Indomethacin.

Figure 1: Anti-inflammatory of methanolic extraction of fruits of Ficus hispida in carrageenan induced rat's model.

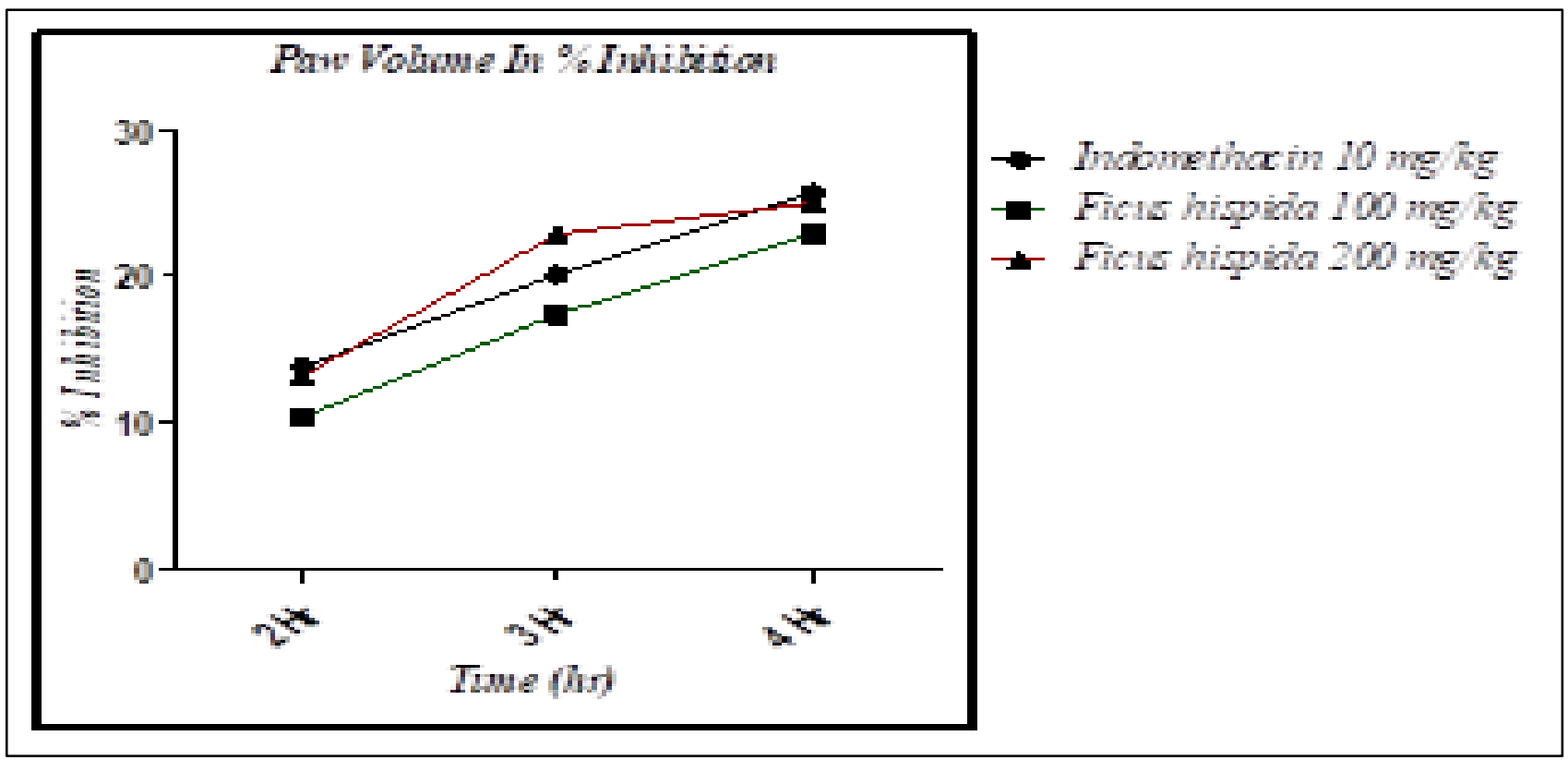

Figure 2: Paw volume in percent inhibition at different interval of time in carrageenan induced rat's model. 


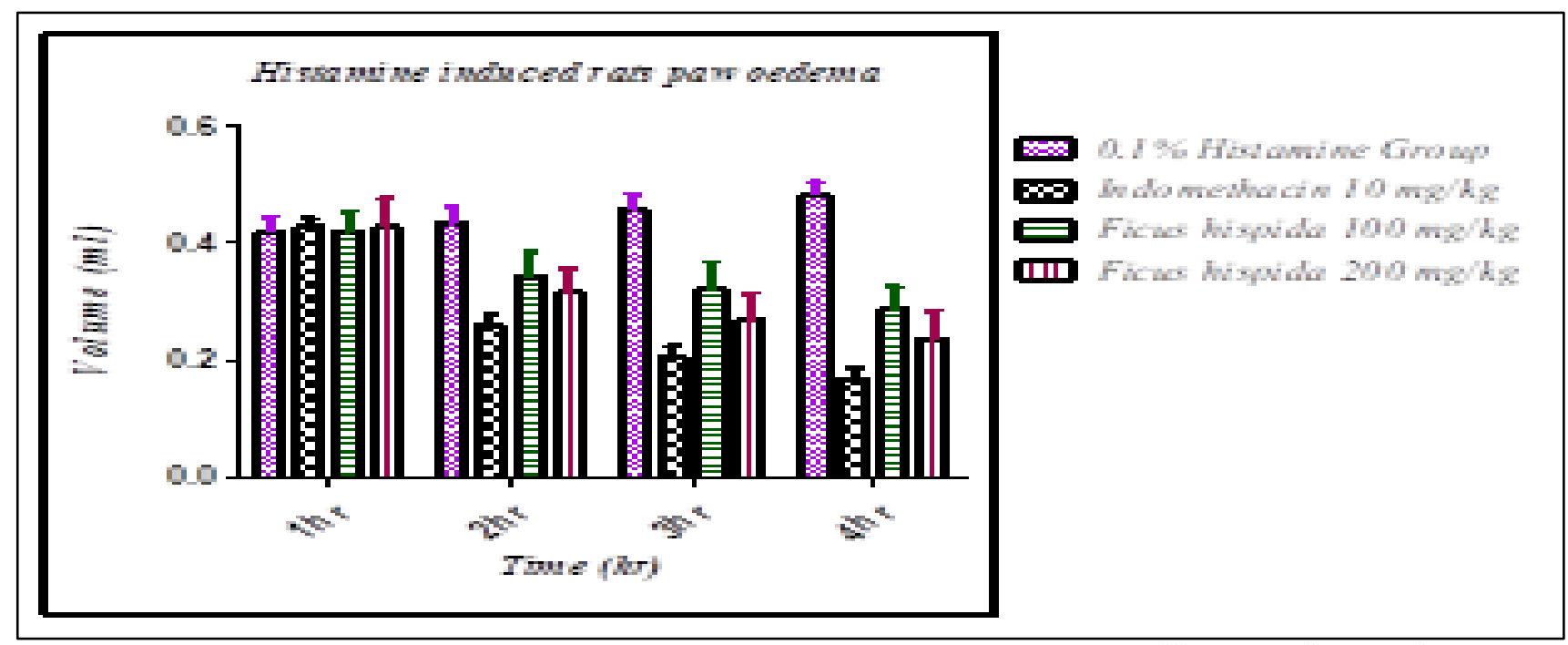

Values are expressed as Mean \pm SEM; $n=6,{ }^{* * *} p<0.001$ when compared with Histamine $(p<0.05) .{ }^{\# \# \#} p<0.001,{ }^{\# \#} p<0.01,{ }^{\#} p<0.05$ when compared with Indomethacin.

Figure 3: Anti-inflammatory of methanolic extraction of fruits of Ficus hispida in histamine induced rat's model.

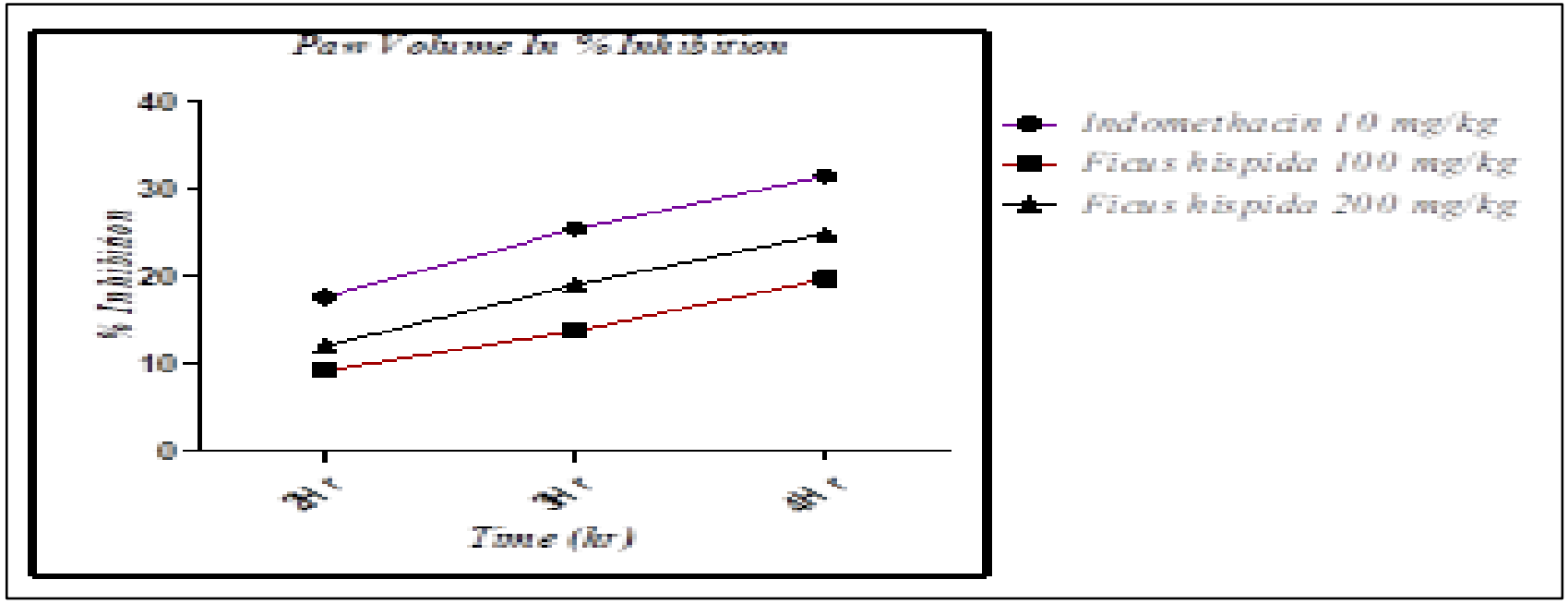

Figure 4: Paw volume in percentage inhibition at different interval of time in histamine induced rat's model.

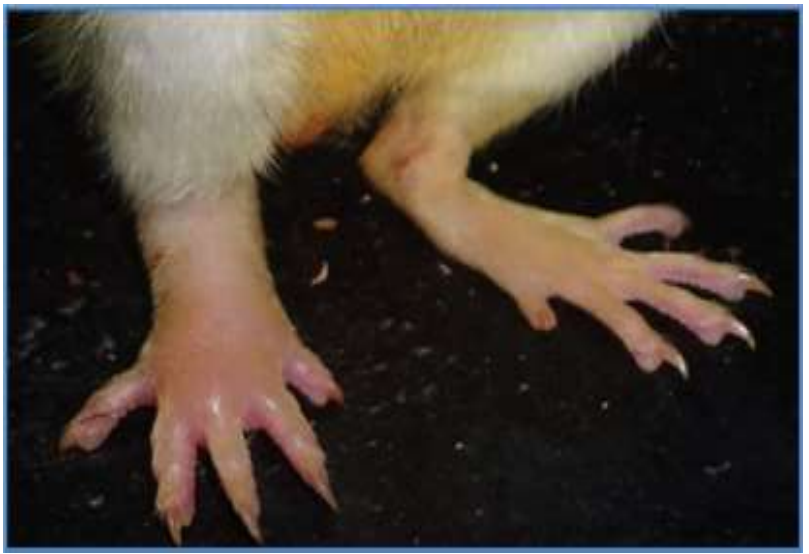

Figure 5: 1 hour after inflammatory agents' injection.

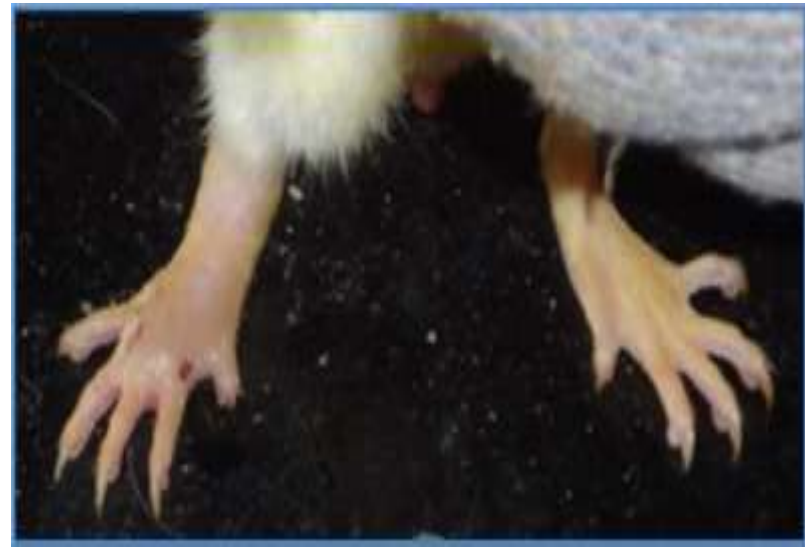

Figure 6: 4 hours after test drug injection. 
In this study, the methanolic extract of fruits of Ficus hispida exerted considerable inhibitory effect on carrageenan induced paw oedema in rats starting from the first hour after administration.

This effect was dose dependent and maximum inhibition induced by the extract was recorded after 4 hours with high dose of Ficus hispida.

\section{Evaluation of in-vitro anti-inflammatory activity}

Table 4: MTT assay-the IC $_{50}$ values of Ficus hispida and indomethacin on RAW 264.7

\begin{tabular}{|ll|}
\hline Samples & $\mathrm{IC}_{50}(\mu \mathrm{g} / \mathrm{ml})$ \\
\hline Ficus Hispida & 125 \\
\hline Indomethacin & 50 \\
\hline
\end{tabular}

Control group received an equivalent volume of vehicle only, standard group received indomethacin at the dose of $2.5 \mu \mathrm{g} / \mathrm{ml}$ and test drug Ficus hispida extract received 50 $\mu \mathrm{g} / \mathrm{ml}$ respectively.

In vitro anti-inflammatory assay on RAW 264.7 cells and measuring the levels of inflammatory cytokines of IL-1 beta, IL-6 and TNF-alpha by ELISA assay.

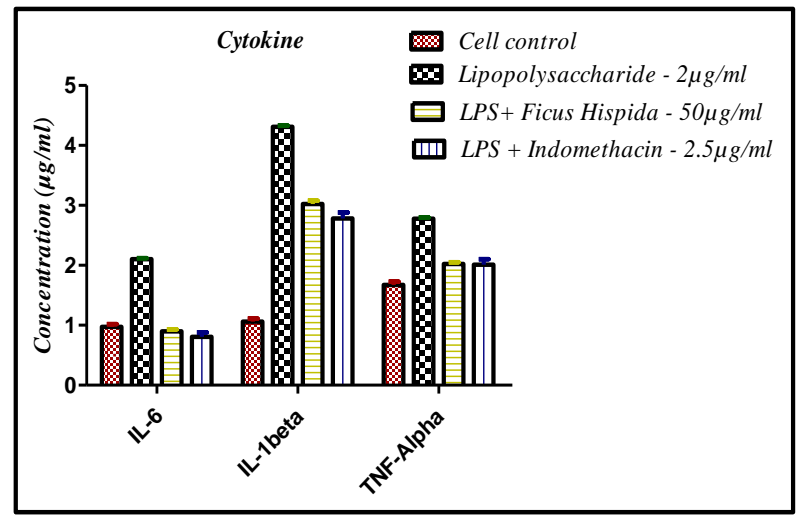

Values are expressed as mean $\pm S E M ; n=3^{* * *} p<0.001$ when compared with LPS, ${ }^{\# \#} p<0.001,{ }^{\# \#} p<0.01$ when compared with Indomethacin.

Figure 7: Cytokine ELISA.

Ficus hispida at a final concentration of $50 \mu \mathrm{g} / \mathrm{ml}$ has been found to reduce the production of all the three proinflammatory cytokines viz, IL-6, IL- $1 \beta$ and TNF- $\alpha$ as compared to the LPS control.

\section{DISCUSSION}

In an effort to search for novel anti-inflammatory agents from Natural plants, more than 300 plant extracts were tested for their ability to reduce the inflammation production. The methanolic extract of Ficus hispida dried fruits effective inhibition of inflammation release; this consequently led to contain oleanolic acid, bergapten, $\beta$ sitosterol, $\quad \beta$-amyrin, hispidin, 10 -ketotetracosyl arachidate, lupeol acetate, $\beta$-amyrin and triacontanol acetate, linalool, linalool oxide, terpeneol, and 2, 6dimethyl-1, 7-octadiene-3, 6-diol, additionally includes ficushispimines $\mathrm{A}$ and $\mathrm{B}$, ficushispidine, hispiloscine, $\mathrm{N}$ triacontanyl acetate, ficusin A, newly isolated two enormous phenanthroindolizidine alkaloids, 6-Omethyltylophorinidine and 2-demethoxytylophorine, and a novel biphenyl hexahydro-indolizine hispidine being responsible for the observed activity. ${ }^{5-7}$

To the best of our knowledge this is the first time their isolation from the species Ficus hispida is reported. Moreover, this is the first time the compounds were shown to reduce pro-inflammatory production. In order to evaluate the compound's activity, we further examined the anti-inflammatory effects of this compound on other inflammatory models, cytokines and mediators. In the present study, carrageenin-induced paw oedema in rats and histamine-induced paw oedema were selected to represent models of acute inflammations. Control group received an equivalent volume of vehicle only, standard group received Indomethacin at the dose of $10 \mathrm{mg} / \mathrm{kg}$ and test drug Ficus hispida extract received low dose $100 \mathrm{mg} / \mathrm{kg}$ and high dose $200 \mathrm{mg} / \mathrm{kg}$ P.O. respectively. And study revealed that there were significantly changes in test group when we were compared with their respective control. However, despite the fact that the inflammatory response can be triggered by different routes, even though we had got 20 to $30 \%$ inhibition after 4 hours in Ficus hispida 100 and $200 \mathrm{mg} / \mathrm{kg}$ respectively in carrageenan induced rat paw oedema model in this study, the methanolic extract of fruits of Ficus hispida exerted considerable inhibitory effect on carrageenan induced paw oedema in rats starting from the first hour after administration. Similarly inhibitory effects of Ficus hispida administered orally on histamine induced paw oedema and the percentage inhibition was $20 \%$ in Ficus hispida $100 \mathrm{mg} / \mathrm{kg}$ and $25 \%$ inhibition in Ficus hispida $200 \mathrm{mg} / \mathrm{kg}$. This effect was dose dependent and maximum inhibition induced by the extract was recorded after 4 hours with high dose of Ficus hispida.

Performing MTT-based cytotoxicity assay of the 'test compounds' on the cell line was to determine the $\mathrm{IC}_{50}$ for fixing the dose for in-vitro anti-inflammatory. The $\mathrm{IC}_{50}$ of Ficus hispida on raw 264.7 cell line has been found to be $125 \mu \mathrm{g} / \mathrm{ml}$. The $\mathrm{IC}_{50}$ of indomethacin on RAW264.7 cell line has been found to be $50 \mu \mathrm{g} / \mathrm{ml}$. The concentrations of IL-6, IL- $1 \beta$ and TNF- $\alpha$, secreted by the cells after challenging with bacterial LPS $(2 \mu \mathrm{g} / \mathrm{ml})$ and subsequent treatment with $50 \mu \mathrm{g}$ Ficus hispida have been found to be $0.897, \quad 3.024$ and $2.023 \mu \mathrm{g} / \mathrm{ml}$ respectively. The concentrations of IL- 6 , IL- $1 \beta$ and TNF- $\alpha$, for cell control (without LPS and drug) have been found to be 0.974, 1.059 and $1.672 \mu \mathrm{g} / \mathrm{ml}$ respectively. The concentrations of IL-6, IL-1 $\beta$ and TNF- $\alpha$, for LPS control (cells challenged with LPS; without drug) have been found to be 2.101, 4.312 and $2.776 \mu \mathrm{g} / \mathrm{ml}$ respectively. The concentrations of IL-6, IL$1 \beta$ and TNF- $\alpha$ secreted by cells treated with Indomethacin $(2.5 \mu \mathrm{g})$ have been found to be $0.805,2.783$ and 2.012 
$\mu \mathrm{g} / \mathrm{ml}$ respectively. Ficus hispida at a final concentration of $50 \mu \mathrm{g} / \mathrm{ml}$ has been found to reduce the production of all the three pro-inflammatory cytokines viz, IL-6, IL-1 $\beta$ and TNF- $\alpha$ as compared to the LPS control.

\section{CONCLUSION}

This chapter describes about anti-inflammatory activity of Ficus hispida dried fruits extracts in carrageenan and histamine induced paw oedema in rats. The crude extract from the Ficus hispida plant produced significant antiinflammatory activity. Since methanolic extracts have produced lower activity than disease control which almost equal active with standard drug. The results were expressed as maximal paw oedema (maximal peak during the 4 hours) and as total paw oedema and presented as mean \pm SEM, $\mathrm{n}=6$. The Ficus hispida extract was further subjected to in vitro anti-inflammatory activity. Ficus hispida at a final concentration of $50 \mu \mathrm{g} / \mathrm{ml}$ has been found to reduce the production of all the three pro-inflammatory cytokines viz, IL-6, IL-1 $\beta$ and TNF- $\alpha$ as compared to the LPS control. The activity, in fact, is comparable to the standard NSAID Indomethacin. These all findings and phytoconstituents present in the extract could be the possible chemicals involved in the prevention of inflammations.

\section{ACKNOWLEDGEMENTS}

The author would like to thanks to department of pharmacology, Karnataka college of pharmacy, Bangalore, India for their support.

Funding: No funding sources Conflict of interest: None declared

Ethical approval: The study was approved by the Institutional Ethics Committee

\section{REFERENCES}

1. Vernonia. Wikipedia, the free encyclopaedia. Available at: en.wikipedia.org/wiki/Vernonia. Accessed on 10 Jan, 2021.

2. Mitchell RN, Cotran RS. Robinson's basic pathology $7^{\text {th }}$ ed. New Delhi: Harcourt (India) Pvt Ltd; 2 Ialenti A, Ianaro A, Moncada S, Di Rosa M. Modulation of acute inflammation by endogenous nitric oxide. Eur $\mathbf{J}$ Pharmacol. 1992;211(2):177-82.

3. Di Rosa M, Willoughby DA. Screening for antiinflammatory drugs. J Pharm Pharmacol. 1971;23(4):297-8.

4. Ripu M, Kunwar I, Rainer WB. Ficus species in Nepal; a review of diversity and indigenous uses. J Ecol. 2006;11:85-7.

5. Shi ZF, Lei C, Yu BW, Wang HY, Hou AJ. New alkaloids and $\alpha$-glucosidase inhibitory flavonoids from Ficus hispida. Chemi Biodiversity. 2016;13(4):445-50.

6. Yap VA, Loong BJ, Ting KN. Hispidacine, an unusual 8, 4'-oxyneolignan-alkaloid with vasorelaxant activity, and hispiloscine, an antiproliferative phenanthroindolizidine alkaloid, from Ficus hispida Linn. Phytochem. 2015;109:96102.

7. Sharma PC, Yelne MB, Dennis TJ. Database on medicinal plants used in Ayurveda, Central Council for Research in Ayurveda and Siddha, New Delhi, India. 2002;5.

8. Nadkarni KM. Indian materiamedica, Popular Prakashan, Mumbai, India. 1976;1.

9. Rastogi R, Mehrotra BN. Compendium Indian Medicinal Plants, CDRI, Lucknow, Publication and Information Directorate, New Delhi, India. 1993;2.

10. Mandal SC, Kumar CKA. Studies on the antidiarrhoeal activity of Ficus hispida. Leaf extract in rats. Fitoterapia. 2002;73(7-8):663-67.

11. Ghosh R, Sharatchandra K, Rita S, Thokchom IS. Hypoglycemic activity of Ficus hispida (bark) in normal and diabetic Albino rats. Indian J Pharmacol. 2004;36(4):222-5.

12. Kone WM, Atindehou KK, Terreaux C, Hostettmann $\mathrm{K}$, Traore D, Dosso M. Traditional medicine in North C`ote-d'Ivoire: screening of 50 medicinal plants for antibacterial activity. J Ethnopharmacol. 2004;93(1):43-9.

13. Mandal SC, Saraswathi B, Kumar CKA, Lakshmi SM, Maiti BC. Protective effect of leaf extract of Ficus hispida Linn. Against paracetamol-induced hepatotoxicity in rats. Phytotherapy Res. 2000;14(6):457-9.

14. Saha MR, Shill MC, Biswas SK, Faruque A. In-vitro antioxidant and cytotoxic activities of methanolic leaf extract of Ficus hispida Linn. Stamford J Pharma Sci. 2011;3(2):29-36.

15. Shanmugarajan TS, Arunsundar M, Somasundaram I, Krishnakumar E, Sivaraman D, Ravichandiran V. Cardioprotective effect of Ficus hispida Linn. On cyclophosphamide provoked oxidative myocardial injury in a rat model. Int J Pharmacol. 2008;4(2):7887.

16. Peraza-S'anchez SR, Chai HB, Young GS. Constituents of the leaves and twigs of Ficus hispida. Planta Medica. 2002;68(2):186-8.

17. Wang L, Wang $\mathrm{X}, \mathrm{Wu} \mathrm{H}$, Liu R. Overview on biological activities and molecular characteristics of sulphated polysaccharides from marine green algae in recent years. Mar Drugs. 2014;12(9):4984-5020.

18. Sharada LD, Somshekhar SK. Isolation and characterization of phytoconstituents from Chlorophytum borivilianum, Pharmacognosy Res. 2010;2:343

19. Gini TG, Jeya Jothi G. Preliminary Phytochemical Screening. Int $\mathrm{J}$ Pharmacognos Phytochem Res. 2013;5(3):200-14.

20. Anjamma M, Bhavani LN. Comparative Phytochemical Constituents Evaluation from the Fruit Extracts of Momordica charantia L. and Momordica dioica Roxb. Int J Curr Biotechnol. 2015;3(8):17-21.

21. Burke RW, Diamondstone BI, Velapoldi RA, Menis O. Mechanisms of the Liebermann-Burchard and Zak 
Color Reactions for Cholesterol, Clin Chem. 1974;20(7):794-801.

22. Suleyman H, Demirezer LO, Kuruuzum A, Banoglu ZN, Gocer F, Ozbakir G et al. Anti-inflammatory effect of the aqueous extract from Rumex patientia $\mathrm{L}$. roots. J Ethnopharmacol. 1991;65:141-8.

23. Mary S, Kala J, Tresina PS, Mohan VR. Evaluation of anti-inflammatory activity of Eugenia singampattiana Bedd leaf. Int J Adv Res. 2013;6(1):248-51.

24. Tamaddonfard E, Farshid AA, Hosseini L. Crocin alleviates the local paw edema induced by histamine in rats. Avicenna J Phytomed. 2012;2(2):97-104.

25. Freshney IR. Cytotoxicity. Culture of animal cells: A manual of basic technique, fifth edition. John Wiley and Sons, Inc. 2005;59.

26. Subash Babu P Alshatwi AA. Aloe-Emodin Protects RIN-5F (Pancreatic $\beta$-cell) Cell from Glucotoxicity via Regulation of Pro-Inflammatory Cytokine and down regulation of Bax and Caspase 3. Biomol Ther. 2016;24(1):49-56.

27. Kowalczyk T, Sitarek P, Skala E, Toma M, Wielanek $\mathrm{M}$. Induction of apoptosis by in vitro and in vivo plant extracts derived from Menyanthes trifoliata L. in human cancer cells. Cytotechnol. 2019;71:165-80.

28. Diosdado MA, Mallado Gill JM. Assay for high glucose-mediated islet cell sensitization to apoptosis induced by streptozotocin and cytokines. Biol. Proceed Online. 2005;7(1):162-71.

29. Sydor S, Jafoui S, Wingerter L, Swoboda S. Bcl-2 degradation is an additional pro-apoptotic effect of polo-like kinase inhibition in cholangio-carcinoma cells. World J Gastroenterol. 2017;23(22):4007-15.

30. Mckenzie MD, Jamieson E, Jansen ES, Scott CL, Huang DCS. Glucose Induces Pancreatic Islet Cell Apoptosis That Requires the BH3-Only Proteins Bim and Puma and Multi-BH Domain Protein Bax. Diabetes. 2010;59:644-52.

Cite this article as: Choudhury A, Jha DK, Rajashekhar U. Anti-inflammatory activity of methanolic extract of Ficus hispida dried fruit. Int J Basic Clin Pharmacol 2021;10:997-1004. 